\title{
ANALISIS PENGARUH MODAL SENDIRI, MODAL LUAR, VOLUME USAHA, DAN TINGKAT PERPUTARAN PIUTANG TERHADAP SISA HASIL USAHA
}

\author{
Oleh: \\ Gaviota Gilda Putri ${ }^{1)}$ \\ Drs. H. Bambang Sunarko, M.M. ${ }^{2)}$ \\ Retno Widuri, SE, M.Si ${ }^{3)}$ \\ E-mail : gaviota.gilda@gmail.com \\ ${ }^{1)}$ Mahasiswa Fakultas Ekonomi dan Bisnis Universitas Jenderal Soedirman \\ ${ }^{2)}{ }^{3)}$ Dosen Fakultas Ekonomi dan Bisnis Universitas Jenderal Soedirman
}

\begin{abstract}
The purpose of this research was to describe the development of cooperatives, to investigate the influence of own capital, loan capital, bussines volume, and receivable turn over on added value of cooperatives. The samples of this research were financial statements in Sejati Mulia business cooperatives, Ceger Jaya busiess cooperatives, and Tunas Jaya business cooperatives from 2004-2014. The method of this research was purposive sampling. The technique of data analysis used was linier multiple regression with classical assumption. The result indicated that own capital,loan capital, bussines volume, and receivable turn over have the positive effect on added value of cooperatives.
\end{abstract}

Keywords: Own Capital, Loan Capital, Bussines Volume, Receivable Turn Over, Added Value of Cooperatives.

\section{PENDAHULUAN}

Kemajuan zaman yang membawa masalah-masalah telah menyebabkan semakin pentingnya fungsi pemasar dalam memasarkan produknya agar mampu memecahkan masalah-masalah yang dihadapi dengan memuaskan. Hal ini disebabkan karena semakin ketatnya persaingan antara perusahaan yang berlomba-lomba untuk memperoleh laba yang maksimal dan untuk mempertahankan kehidupan perusahaan. Persaingan ketat tidak hanya dialami oleh 


\section{Performance - Vol.23 No.2 September 2016}

perusahaan-perusahaan atau organisasiorganisasi yang bergerak disekitar perdagangan dan produksi barang saja, melainkan juga pada perusahaan yang bergerak pada bidang pelayanan jasa seperti Koperasi.

Ide berdirinya koperasi dimulai karena adanya kecemburuan dari beberapa buruh yang bekerja di suatu pabrik terhadap sistem kapitalisme awal yang sangat menguntungkan satu pihak yaitu pemilik modal. Akibatnya kaum kapitalis memperoleh keuntungan yang besar dan tingkat kesejahteraan kaum buruh menjadi sangat rendah, artinya buruh dituntut untuk bekerja dalam waktu yang panjang dengan tingkat upah yang kecil, sehingga timbul jurang pemisah antara pengusaha atau para pemilik modal dengan kaum buruh yang miskin. Suasana ini yang membuat beberapa orang mulai tergugah untuk meningkatkan kesejahteraan secara bersama pula. Itulah cikal bakal lahirnya ide atau gagasan untuk membentuk koperasi.

Koperasi mempunyai peran penting dalam tercapainya kesejahteraan bagi anggota khususnya dan masyarakat pada umumnya. Koperasi dalam kegiatannya memiliki dua karakter yang khas yaitu bersifat mementingkan pendidikan perkoperasian bagi anggota dan masyarakat (Anoraga dan Widiyanti, 2002:17).

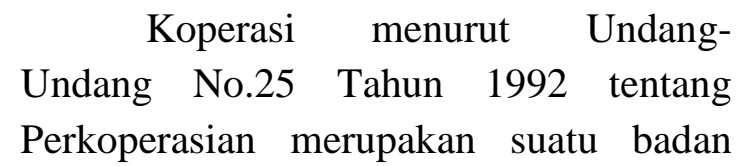

usaha, sehingga koperasi tetap tunduk terhadap kaidah-kaidah perusahaan dan prinsip-prinsip ekonomi yang berlaku serta koperasi juga merupakan suatu organisasi ekonomi yang menitikberatkan kegiatannya pada ekonomi kerakyatan mempunyai ciri-ciri demokratis, kebersamaan dan kekeluargaan. Karena itu, koperasi harus dapat menghasilkan keuntungan dalam mengembangkan organisasi dan usahanya.

Koperasi sebagai bagian dari tata perekonomian nasional memiliki peran yang sangat strategis dalam perkembangan potensi ekonomi rakyat. Dalam UU No. 25 tahun 1992 disebutkan juga bahwa koperasi bertujuan untuk memajukan kesejahteraan anggota pada khususnya dan masyarakat pada umumnya serta membangun tatanan masyarakat yang adil dan makmur berdasarkan pancasila dan UUD 1945. Karena merupakan badan usaha maka koperasi mempunyai dua tujuan sekaligus yaitu tujuan yang bersifat ekonomis dan tujuan yang bersifat sosial. Tujuan yang bersifat ekonomis yaitu koperasi merupakan suatu badan usaha yang menjalankan kegiatan ekonomi untuk mendapatkan laba atau Sisa Hasil Usaha (SHU) sebagai salah satu usaha untuk meningkatkan kesejahteraan para anggota. Tujuan yang bersifat sosial yaitu koperasi merupakan kumpulan orang-orang yang bekerja sama dalam suatu organisasi yang berasaskan kekeluargaan untuk mencapai kesejahteraan bersama (Anoraga, 2003) 
Ekonomi Rakyat adalah sub sistem ekonomi nasional dan global yang dalam pengembangannya berupaya untuk menata kehidupan sehari hari rakyat kecil dan masyarakat menengah ke bawah dalam memenuhi kebutuhan hidupnya. Sistem tersebut mengandung norma norma yang mampu mengatur perilaku dan pola pikir. Perilaku dan pola pikir pelaku ekonomi rakyat tersebut sebagian besar masih berwatak asli rakyat desa seperti kebersamaan dan musyawarah. Motif ekonomi dan watak kewirausahaan karenanya berjalan lambat. Di samping sebab-sebab yang sifatnya kultural tersebut, ada pula sebab yang sifatnya natural (dukungan sumber daya alam) ataupun yang sifatnya struktural (sistem sosio ekonomi politik). Tentunya ada pula pengaruh eksternal historis seperti kolonialisme, kapitalisme, sosialisme, agama serta gerakan lingkungan. Tujuan pemberdayaan dan pengembangan ekonomi rakyat adalah untuk memperbaiki kehidupan ekonomi rakyat ke arah kemajuan rakyat dan melepaskan hambatan dari berbagai sebab tersebut (Hakim,2000).

Dalam rangka memperluas kesempatan berusaha bagi masyarakat untuk melakukan kegiatan produktif, dipandang perlu untuk menumbuhkembangkan Koperasi Simpan Pinjam dan atau Unit Simpan Pinjam agar masyarakat memperoleh manfaat yang sebesar-besarnya untuk kesejahteraannya. Berdasarkan pasal 44 UU No. 25 Tahun 1992 tentang Perkoperasian dan penjelasannya telah diatur bahwa koperasi dapat menghimpun dana dan menyalurkannya melalui kegiatan usaha simpan pinjam. Kegiatan usaha pinjam tersebut dilaksanakan dari dan untuk anggota koperasi yang bersangkutan, calon anggota yang memenuhi syarat dan koperasi lain dan atau anggotanya. Ketentuan ini menjadi dasar hukum yang kuat bagi koperasi untuk melaksanakan kegiatan usaha simpan pinjam baik sebagai salah satu ataupun satu-satunya kegiatan usaha koperasi, sebagai penghimpun dan penyalur dana masyarakat walaupun dalam lingkup yang terbatas. Dalam pencapaian tujuan tersebut, suatu koperasi memerlukan pemberdayaan yang meliputi pemanfaatan sumber daya manusia dan pemanfaatan sumber daya lainnya yaitu pada bidang usaha yang tercermin dalam laporan keuangan.

Pembangunan koperasi yang merupakan perwujudan ke arah amanat konstitusi bangsa Indonesia, yaitu pada Undang-Undang Dasar 1945 khususnya pasal 33 ayat (1) yaitu perekonomian Indonesia disusun sebagai usaha bersama berdasarkan atas asas kekeluargaan dan koperasi adalah bangunan usaha yang sesuai dengan susunan perekonomian yang dimaksud. Oleh karena itu, koperasi diharapkan memainkan peranan penting dalam perekonomian Indonesia, yaitu koperasi sebagai soko guru perekonomian Indonesia. Selain itu koperasi juga merupakan salah satu pelaku ekonomi yang disusun dan dijalankan sebagai 


\section{Performance - Vol.23 No.2 September 2016}

usaha bersama dari anggota dan untuk kesejahteraan seluruh anggota. Untuk mengembangkan usaha agribisnis skala kecil perlu dibentuk koperasi, tanpa koperasi tidak mungkin agribisnis kecil dapat berkembang. Lewat koperasi masyarakat pedesaan dapat belajar berbagai hal tidak hanya belajar bertani, berternak, dan berkebun tetapi dapat belajar pemasaran, manajemen, dan administrasi keuangan.

Dalam sistem perekonomian yang berdasarkan Pancasila dan UUD 1945, koperasi merupakan salah satu dari tiga kekuatan perekonomian yang saling terkait yaitu perekonomian negara, swasta dan koperasi. Koperasi sebagai salah satu sektor kekuatan ekonomi diharapkan dapat dijadikan sebagai soko guru perekonomian Indonesia, karena koperasi merupakan suatu badan usaha yang sesuai dengan demokrasi ekonomi bangsa Indonesia yaitu dari rakyat, oleh rakyat dan untuk kesejahteraan rakyat.

Menurut Sitio (2001:142) usaha atau kegiatan yang dilakukan koperasi dapat dilihat dari besarnya volume usaha koperasi itu sendiri. Volume usaha inilah yang nantinya akan berpengaruh terhadap perolehan SHU koperasi.

Piutang sebagai bagian dari modal kerja, keberadaannya akan selalu berputar, dalam arti piutang itu akan tertagih pada saat tertentu. Periode perputaran piutang tergantung pada panjang pendeknya ketentuan waktu yang dipersyaratkan dalam syarat pembayaran kredit. Sehingga semakin lama syarat pembayaran kredit berarti semakin lama terikatnya modal kerja dalam piutang. Sebaliknya semakin pendek syarat pembayaran kredit berarti semakin pendek tingkat terikatnya modal kerja dalam piutang. Dengan mengetahui tingkat perputaran piutang, maka akan diketahui tingkat efektivitas modal kerja yang tertanam dalam piutang.

Berdasarkan uraian yang telah dikemukakan diatas, maka peneliti tertarik untuk melakukan penelitian tentang "Analisis Pengaruh Modal Luar, Modal Sendiri, Volume Usaha, dan Tingkat Perputaran Piutang Koperasi terhadap Sisa Hasil Usaha".

\section{Perumusan Masalah Penelitian}

1. Apakah Modal Sendiri mempunyai pengaruh terhadap SHU?

2. Apaklah Modal Luar mempunyai pengaruh terhadap SHU?

3. Apakah Volume Usaha mempunyai pengaruh terhadap SHU?

4. Apakah Tingkat Perputaran Piutang mempunyai pengaruh terhadap SHU? 


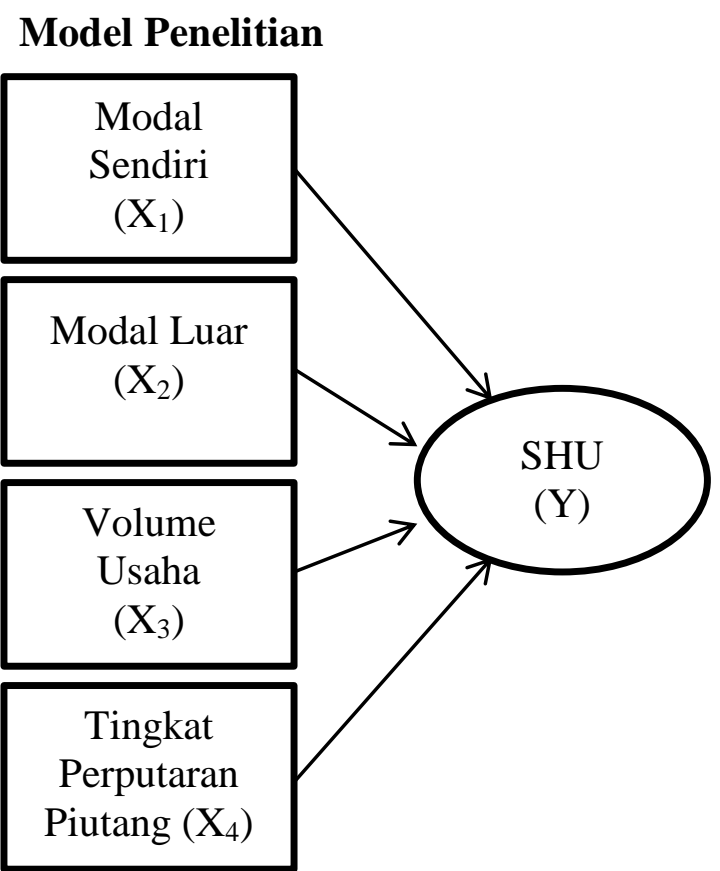

\section{Hipotesis Penelitian}

$\mathrm{H}_{1}$ : Modal sendiri (X1) berpengaruh secara positif signifikan terhadap SHU (Y) koperasi.

$\mathrm{H}_{2}$ : Modal Luar (X2) berpengaruh secara negatif signifikan terhadap SHU (Y) koperasi.

$\mathrm{H}_{3}$ : Volume usaha (X3) berpengaruh secara positif signifikan terhadap SHU (Y) koperasi.

$\mathrm{H}_{4}$ : Tingkat perputaran piutang (X4) berpengaruh secarapositif signifikan terhadap SHU (Y) koperasi.

\section{METODE ANALISIS}

\section{Objek Penelitian}

Objek penelitian dalam penelitian ini adalah SHU, Modal Luar, Modal Sendiri, Volume Usaha, dan Tingkat Perputaran Piutang Koperasi pada KSU Sejati Mulia, KSU Tunas Jaya, dan KSU Ceger Jaya.

\section{Populasi dan Sample Penelitian}

Populasi yang digunakan dalam penelitian ini adalah data laporan keuangan KSU Sejati Mulia, KSU Tunas Jaya, dan KSU Ceger Jaya di Jakarta.Sampel penelitian ini adalah data laporan keuangan tahun 2006-2015.

\section{Jenis dan Sumber Data}

Data yang digunakan dalam penelitian ini adalah data sekunder. Data ini dapat diperoleh dari dokumen dan laporan tahunan (RAT) yang diperlukan dalam penelitian ini di KSU Sejati Mulia, KSU Tunas Jaya, dan KSU Ceger Jaya, sumber literatur, internet dokumentasi dan data pendukung lainnya. Data berupa laporan keuangan dari tahun 2006 hingga 2015. Pengambilan data dilakukan secara time series.

\section{Definisi Operasional Variabel}

1. Variabel Dependen

a. Sisa Hasil Usaha (SHU)

Sisa Hasil Usaha adalah pendapatan koperasi yang diperoleh dalam satu tahun buku dikurangi dengan biaya, penyusutan, dan kewajiban lainnya, pajak dalam tahun buku yang bersangkutan. 
2. Variabel Independen

a. Modal Sendiri $\left(\mathrm{X}_{1}\right)$

Modal Sendiri merupakan kumulatif dari simpanan pokok, simpanan wajib, dana cadangan, dan hibah.

b. Modal Luar $\left(\mathrm{X}_{2}\right)$

Modal Luar merupakan modal yang dipinjam koperasi yang berasal dari anggota, koperasi lainnya, bank/lembaga keuangan, penerbitan obligasi/surat berharga, dan sumber lainnya.

c. Volume Usaha $\left(\mathrm{X}_{3}\right)$

Volume Usaha adalah total nilai penjualan/pendapatan barang dan jasa pada tahun buku yang bersangkutan.

d. Perputaran Piutang $\left(\mathrm{X}_{4}\right)$

Periode perputaran piutang tergantung dari panjang pendeknya ketentuan waktu yang dipersyaratkan dalam syarat pembayaran, sehingga semakin lama syarat pembayaran kredit berarti semakin lama terikatnya modal kerja tersebut dalam piutang dan berarti semakin kecil tingkat perputaran piutang dalam satu periode dan begitu pula sebaliknya", (Bambang Riyanto, hal.3.)

Perputaran piutang dalam satu periode dapat dihitung dengan rumus :

$$
\text { Perputaran Piutang }=\frac{\text { Penjualan Kredit }}{\text { Rata-rata Piutang }}
$$

\section{Teknis Analisis Data}

Analisis data yang digunakan dalam penelitian ini adalah uji analisis regresi linier berganda dengan menggunakan SPSS 16.00 for windows.

1. Uji Asumsi Klasik

a. Uji Normalitas

Pengujian Normalitas pada penelitian ini menggunakan uji Kolmogorov-Smirnov, hasil nilai asymp. sig. (2-tailed) untuk unstandardized variable sebesar 0,878 lebih besar dari nilai $\alpha$ yaitu 0,05 . Maka data dinyatakan menyebar berdistribusi dengan normal dan layak menggunakan regresi. Ringkasan uji normalitas disajikan pada tabel 1 . Hasil uji normalitas tercantum pada lampiran 2a.

Tabel 1. Ringkasan Hasil Uji Normalitas Kolmogorov-Smirnov

\begin{tabular}{|c|c|c|c|}
\hline & Kolmog & & \\
\hline $\begin{array}{l}\text { Standardiz } \\
\text { ed } \\
\text { Residual }\end{array}$ & $\begin{array}{l}\text { orov- } \\
\text { Smirno } \\
v\end{array}$ & $\begin{array}{l}\text { Asymp } \\
\text {.Sig (2- } \\
\text { tiled })\end{array}$ & $\begin{array}{l}\text { Keteran } \\
\text { gan }\end{array}$ \\
\hline Normalitas & .590 & .878 & Normal \\
\hline
\end{tabular}

Sumber : data diolah

b. Uji Multikolinieritas 
http://jp.feb.unsoed.ac.id

Pada penelitian ini ringkasan hasil yang uji multikolinieritas disajikan pada tabel 2 .

Tabel 2. Ringkasan Hasil Uji Multikolinieritas

\begin{tabular}{lll}
\hline Variable & Tolerance & VIF \\
\hline Modal Sendiri & .262 & 3.810 \\
Modal Luar & .231 & 4.332 \\
Volume Usaha & .451 & 2.217 \\
T. Perp. Piutang & .285 & 3.504 \\
\hline \multicolumn{2}{c}{ Sumber : data diolah }
\end{tabular}

Variabel dinyatakan terbebas dari multikolinieritas jika nilai hasil VIF lebih kecil dari 10 (Suliyanto, 2011;90). Dari tabel 2 dapat diketahui bahwa seluruh variabel memiliki nilai VIF lebih kecil dari 10 dan tolerance lebih besar dari 0,1 maka data dari penelitian ini dinyatakan terbebas dari asumsi multikolinieritas.

c. Uji Heteroskedastisitas

Uji heteroskedastisitas dalam penelitian ini menggunakan metode Park. Jika nilai probabilitas lebih besar dari nilai alpha (Sig. $>\alpha$ ) atau $t_{\text {hitung }}<t_{\text {tabel }}$ maka model dikatakan tidak mengandung gejala heteroskedastisitas (Suliyanto, 2011;102). Ringkasan hasil pengujian disajikan pada tabel 3 .

Tabel 3. Ringkasan Uji Heteroskedastisitas

\begin{tabular}{lcc}
\hline Variabel & \multicolumn{1}{c}{$t_{\text {hitung }}$} & Sig. \\
\hline Modal Sendiri & 2.669 & .013 \\
Modal Luar & 2.510 & .019 \\
Volume Usaha & .179 & .859 \\
T. Perp. & 2.507 & .019 \\
Piutang & \\
\hline & \\
\multicolumn{3}{c}{ Sumber : data diolah } \\
Tabel 3 menunjukan bahwa \\
seluruh variabel tidak mempunyai \\
pengaruh signifikan terhadap absolut \\
residualnya jadi data dinyatakan \\
terbebas dari \\
heteroskedastisitas.
\end{tabular}

d. Uji Autokorelasi

Uji autokorelasi pada penelitian ini menggunakan BreuschGodfrey (B-G test), yaitu nilai $\mathrm{R}^{2}$ digunakan sebagai dasar untuk menghitung nilai $X^{2}=(n-p) * R^{2}$. Jika nilai $X^{2}$ hitung $\leq X^{2}$ tabel maka menunjukan tidak terjadi masalah autokorelasi (Suliyanto, 2011;137). Ringkasan hasil pengujian disajikan pada tabel 4 .

Tabel 4. Ringkasan Uji Autokorelasi

\begin{tabular}{ccc}
\hline R Square & \multicolumn{2}{c}{$\mathrm{X}^{2}$} \\
\hline 0.667 & 43.770 \\
\hline Sumber : data diolah & & \\
Berdasarkan tabel 5 & dapat \\
disimpulkan bahwa nilai $\mathrm{R}^{2}(0,118)$ \\
digunakan sebagai dasar untuk \\
menghitung nilai $\mathrm{X}^{2}=(30-4)^{*} 0.667=$
\end{tabular}




\section{Performance - Vol.23 No.2 September 2016}

17.342. Karena nilai $X^{2}$ hitung $(17.342) \leq X^{2}$ tabel (43.770) maka menunjukan tidak terjadi masalah autokorelasi atau dengan kata lain tidak terjadi gejala autokorelasi.

2. Analisis Regresi Linier Berganda Pengujian signifikansi pengaruh variabel modal luar, modal sendiri, volume usaha, dan tingkat perputaran piutang terhadap variabel SHU dalam penelitian ini menggunakan analisis regresi linear berganda. Berdasarkan hasil perhitungan statistik dengan bantuan software SPSS 16.0 for Windows, selanjutnya diperoleh ringkasan hasil perhitungan yang dapat dilihat pada Tabel 5.

Tabel 5. Ringkasan Hasil Analisis Regresi Berganda

\begin{tabular}{llll}
\hline Variabel & Koefisien & $t_{\text {hitung }}$ & Sig. \\
\hline (Constant) & -15.994 & -2.270 & .032 \\
Modal Sendiri & .841 & 2.669 & .013 \\
Modal Luar & .700 & 2.510 & .019 \\
VolumeUsaha & .034 & .179 & .859 \\
T.Per.Piutang & .579 & 2.507 & .019 \\
\hline Adjusted $R^{2}$ & & & .613 \\
F Hitung & & & 12.508 \\
F tabel & & & 2.76
\end{tabular}

Sumber : data diolah

Berdasarkan data pada Tabel 5, dapat dibuat persamaan regresi linear berganda sebagai berikut:
$\mathrm{Y}=-15.994+0,841 X_{1}+0,700 X_{2}+0$, $034 X_{3}+0,579 X_{4}+\mathrm{e}$

a. Koefisien Determinasi (Adjusted $R$ Square)

Besarnya pengaruh variabel bebas terhadap variabel terikat pada penelitian ini dapat dilihat dari nilai adjusted r-square sebesar 0,613 yang disajikan dalam tabel 5 dan tercantum pada lampiran 3. Ini berarti bahwa variasi SHU(Y) dapat dijelaskan oleh variabel modal sendiri, modal luar, volume usaha, dan tingkat perputaran piutang sebesar 61,3 persen sedangkan sisanya 38,7 persen dijelaskan oleh variabel yang lain yang tidak dimasukan dalam model.

Tabel 6. Ringkasan Hasil Koefisien Determinasi

\begin{tabular}{ccc}
\hline $\mathrm{R}^{2}$ & $\begin{array}{c}\text { Adjusted } R- \\
\text { Square }\end{array}$ & $\begin{array}{c}\text { Std. Error of } \\
\text { The Estimate }\end{array}$ \\
\hline .667 & .613 & .7889319 \\
\hline \multicolumn{2}{c}{ Sumber $:$ data diolah }
\end{tabular}

b. Pengujian Secara Simultan (Uji F) Berdasarkan pengujian dengan $\alpha=0,05$, diperoleh nilai $\mathrm{F}_{\text {hitung }}$ sebesar 12,508 yang tercantum pada lampiran 3, sedangkan $\mathrm{F}_{\text {tabel }}$ pada df (k-1) dan (n$\mathrm{k})=2,76$. Karena $\mathrm{F}_{\text {hitung }}>\mathrm{F}_{\text {tabel }}$ maka dapat disimpulkan terdapat pengaruh simultan dari variabel modal sendiri, modal luar, volume 
usaha, dan tingkat perputaran piutang terhadap SHU.

c. Pengujian Secara Parsial (Uji $t$ )

Untuk mengetahui secara parsial variabel modal sendiri, modal luar, volume usaha, dan tingkat perputaran piutang terhadap SHU digunakan uji $t$. Adapun hasil analisis dengan menggunakan $\alpha=0,05$ dan df (n-k) diketahui nilai $t_{\text {tabel }}$ bernilai 1,71. Berdasarkan pengujian secara parsial diperoleh ringkasan hasil uji $t$ seperti yang dijelaskan pada tabel 7 .

Tabel 7 . Ringkasan Hasil Uji $t$

\begin{tabular}{lccc}
\hline Variabel & $t_{\text {hitung }}$ & $t_{\text {tabel }}$ & Sig. \\
\hline Modal Sendiri & 2.669 & 1.71 & .013 \\
Modal Luar & 2.510 & 1.71 & .019 \\
Volume Usaha & .179 & 1.71 & .859 \\
T.Perp.Piutang & 2.507 & 1.71 & .019 \\
\hline
\end{tabular}

Sumber : data diolah

\section{Pembahasan Hasil Penelitian}

Dari hasil perhitungan yang diperoleh pada tabel 3, maka dapat disimpulkan :

1. Pengujian Hipotesis Pertama

Berdasarkan hasil penelitian menunjukan bahwa $t_{\text {hitung }}>t_{\text {tabel }}$ $(2,669>1,71)$ dan nilai sig. $<\alpha(0,013<$ 0,05) sehingga $\mathrm{H}_{0}$ ditolak dan $\mathrm{Ha}$ diterima. Dengan demikian hipotesis pertama yang menyatakan Modal Sendiri berpengaruh positif signifikan terhadap SHU diterima. Secara grafik dapat dijelaskan dalam gambar 3.

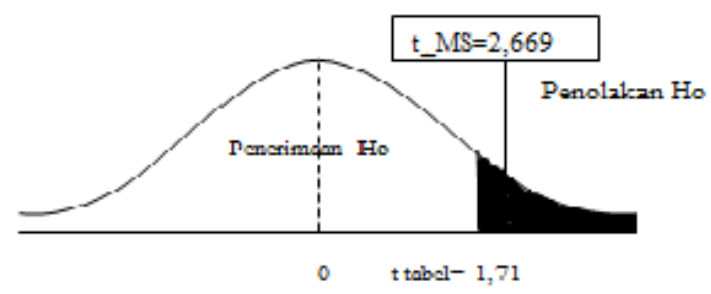

Gambar 3. Kurva Pengujian Hipotesis Pertama dengan Uji t

2. Pengujian hipotesis kedua

Berdasarkan hasil penelitian menunjukan bahwa $t_{\text {hitung }}>t_{\text {tabel }}$ $(2,510>1,71)$ dan nilai sig. $<\alpha(0,019<$ 0,05) sehingga $\mathrm{H}_{0}$ ditolak dan $\mathrm{Ha}$ diterima. Dengan demikian hipotesis kedua yang menyatakan Modal Luar berpengaruh negatif signifikan terhadap SHU ditolak. Karena manajemen dan perkembangan dari KSU Sejati Mulia, KSU Tunas Jaya, dan KSU Ceger Jaya sangat baik, sehingga Modal Luar tidak memberikan pengaruh yang negatif pada SHU. Secara grafik dapat dijelaskan dalam gambar 4. 


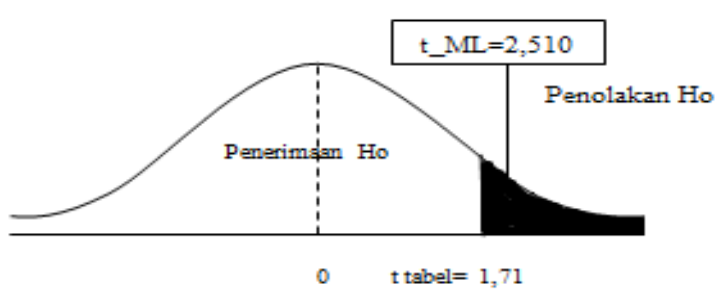

Gambar 4. Kurva Pengujian Hipotesis Kedua dengan Uji t

\section{Pengujian Hipotesis Ketiga}

Berdasarkan hasil penelitian menunjukan bahwa $t_{\text {hitung }}<t_{\text {tabel }}$ $(0,179<1,71)$ dan nilai sig. $>\alpha(0,859>$ 0,05) sehingga $\mathrm{H}_{0}$ ditolak dan $\mathrm{Ha}$ diterima. Dengan demikian hipotesis ketiga yang menyatakan volume usaha berpengaruh positif signifikan terhadap SHU ditolak. Meskipun $t_{\text {hitung }}$ terletak di daerah penerimaan $\mathrm{H} 0$, tetapi $t_{\text {hitung }}<t_{\text {tabel }}$. Secara grafik dapat dijelaskan dalam gambar 5 .

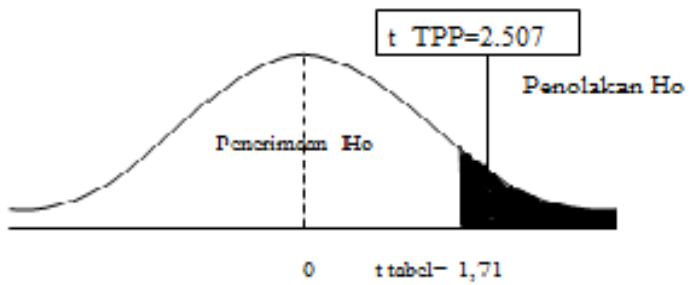

Gambar 5. Kurva Pengujian Hipotesis Ketiga dengan Uji t

\section{Pengujian Hipotesis Keempat}

Berdasarkan hasil penelitian menunjukan bahwa $t_{\text {hitung }}>t_{\text {tabel }}$ $(2,507>1,71)$ dan nilai sig. $<\alpha(0,019$ $<0,05)$ sehingga $\mathrm{H}_{0}$ ditolak dan $\mathrm{Ha}$ diterima. Dengan demikian hipotesis keempat yang menyatakan tingkat perputaran piutangberpengaruh positif signifikan terhadap SHU diterima. Secara grafik dapat dijelaskan dalam gambar 6.

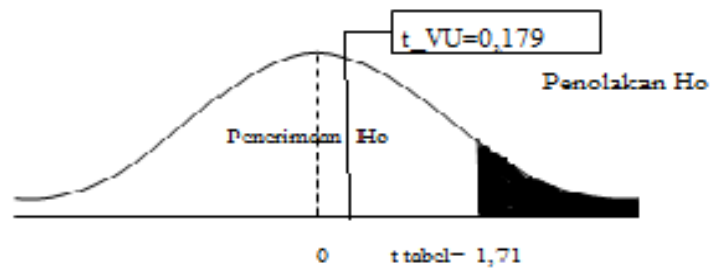

Gambar 6. Kurva Pengujian Hipotesis Keempat dengan Uji $\mathrm{t}$

\section{Pembahasan Hasil Penelitian}

Berdasarkan tabel 3 dapat dilakukan pembahasan hubungan antar variabel sebagai berikut :

1. Pengaruh modal sendiri terhadap SHU koperasi.

Berdasarkan hasil penelitian menunjukan bahwa $t_{\text {hitung }}>t_{\text {tabel }}$ $(2,669>1,71)$ dan nilai sig. $<\alpha(0,013$ $<0,05)$ sehingga $\mathbf{H}_{1}$ diterima. Dalam penelitian ini menyatakan modal sendiri berpengaruh signifikan dengan arah positif terhadap SHU koperasi. Penelitian ini sejalan dengan penelitian Agustin dan Beny (2011)menyatakan bahwa modal sendiri, modal luar, dan volume usaha secara bersama-sama mempengaruhi SHU koperasi.

2. Pengaruh modal luar terhadap SHU koperasi. 
Dari hasil regresi berganda menunjukan bahwa nilai $t_{\text {hitung }}>$ $t_{\text {tabel }}(2,510>1,71)$ dan nilai sig. $<\alpha$ $(0,019<0,05)$ sehingga $\mathbf{H}_{2}$ ditolak karena dalam penelitian ini menyatakan modal luar berpengaruh signifikan dengan arah positif terhadap SHU koperasi.

Hasil penelitian tersebut menunjukan hasil yang sama dengan penelitian Agustin dan Beny (2011) menyatakan bahwa modal sendiri, modal luar, dan volume usaha secara bersama-sama mempengaruhi SHU koperasi.

3. Pengaruh volume usaha terhadap SHU koperasi.

Berdasarkan hasil penelitian menunjukan bahwa $t_{\text {hitung }}<t_{\text {tabel }}$ $(0,179<1,71)$ dan nilai sig. $>\alpha(0,859$ $>0,05)$ sehingga $\mathbf{H}_{\mathbf{3}}$ ditolak. Dalam penelitian ini tidak terdapat pengaruh positif signifikan terhadap SHU koperasi. Hasil ini sejalan dengan teori yang ada bahwa SHU koperasi akan dipengaruhi oleh besar kecilnya modal (baik modal sendiri maupun modal dari luar) dan volume usaha dari koperasi tersebut.

4. Pengaruh tingkat perputaran piutang terhadap SHU koperasi.

Hasil penelitian ini diketahui $t_{\text {hitung }}>t_{\text {tabel }}(2,507>1,71)$ dan nilai sig. $<\alpha(0,019<0,05)$ sehingga $\mathbf{H}_{4}$ diterima dengan arti tingkat perputaran piutang berpengaruh positif signifikan terhadap SHU koperasi.
Penelitian ini menunjukan hasil yang sama dengan penelitian Albertus dan Amelia (2012) yaitu secara parsial perputaran piutang berpengaruh positif signifikan terhadap rentabilitas ekonomi. Rentabilitas merupakan kemampuan koperasi untuk memperoleh SHU.

\section{KESIMPULAN DAN IMPLIKASI}

\section{Kesimpulan}

1. Modal sendiri berpengaruh positif signifikan terhadap sisa hasil usahakoperasi. Hal ini berarti hipotesis yang menyatakan bahwa modal sendiri berpengaruh positif terhadap sisa hasil usaha terbukti.

2. Modal luar berpengaruh positif signifikan terhadap sisa hasil usaha koperasi. Hal ini berarti hipotesis yang menyatakan bahwa modal luar berpengaruh negatif terhadap sisa hasil usaha tidak terbukti.

3. Volume usaha tidakberpengaruh positif signifikan terhadap sisa hasil usaha koperasi. Hal ini berarti hipotesis yang menyatakan bahwa volume usaha berpengaruh positif terhadap sisa hasil usaha tidak terbukti.

4. Tingkat perputaran piutang berpengaruh positif terhadap sisa hasil usaha koperasi. Hal ini berarti hipotesis yang menyatakan bahwa tingkat 


\section{Performance - Vol.23 No.2 September 2016}

perputaran piutang berpengaruh positif terhadap sisa hasil usaha terbukti.

\section{Implikasi}

1. Dalam perolehan sisa hasil usaha, manajemen KSU Sejati Mulia, KSU Ceger Jaya, dan KSU Tunas Jaya perlu memperhatikan faktor modal sendiri, modal luar, volume usaha, dan tingkat perputaran piutangkoperasi karena faktor tersebut terbukti berpengaruh. Selain itu faktor-faktor yang berpengaruh terhadap sisa hasil usaha akan membantu koperasi dalam meningkatkan perolehan SHU dan mensejahterakan anggotanya.

2. Modal sendiri, modal luar, volume usaha, dan tingkat perputaran piutang berpengaruh positif terhadap sisa hasil usaha koperasi. Maka pihak koperasi hendaknya tetap menjaga keseimbangan antara aset koperasi yang digunakan untuk melakukan aktivitas penjualan, simpan pinjam dan aktivitas lain dalam koperasi untuk meningkatkan tingkat perputaran piutang per tahun dan meningkatkan perolehan sisa hasil usaha koperasi.

3. Pihak pengurus koperasi hendaknya lebih bijaksana dalam mengambil keputusan dalam pengelolaan perkembangan volume usaha. Jika volume usaha makin besar, maka perolehan sisa hasil usaha juga makin besar. Jadi pengelolaan volume usaha dapat dikelola secara maksimal dengan SHU yang diperoleh bertambah maka akan berdampak pada meningkatnya nilai koperasi.

4. Pihak koperasi hendaknya memperhatikan pengelolaan modal luar yang ada, jika nilai hutang koperasi meningkat, bahkan jika tidak ada penyelesaiannya maka akan mempengaruhi perolehan SHU koperasi. 


\section{DAFTAR PUSTAKA}

Agustin, Beny, 2011. Pengaruh modal Sendiri, Modal Luar, Dan Volume Usaha pada Sisa Hasil Usaha Koperasi di Provinsi DIY. Universitas Gunadarma Jurusan Akuntansi.

Algifari, 2000. Analisis Regresi, Teori Kasus dan Solusi, BPFE, Yogyakarta.

Albertus ,Amelia, 2012. Pengaruh Perputaran kas Dan Perputaran Piutang Terhadap Rentabilitas Ekonomi Pada KPRI di Lingkungan $B K N$. ESENSI Volume 15 No.2 / Agustus 2012.

Atmadji, 2007. Faktor-Faktor Yang MenentukanBesarnya Sisa Hasil UsahaKoperasi Dari Aspek Keuangan Dan Non-keuangan diIndonesia. Jurnal Bisnis Dan Manajemen.Vol. 7 No. 2. 2007:217232.

Bambang Riyanto,2001.Dasar-dasar Pembelajaran Perusahaan, Edisi ke empat, BPFE, Yogyakarta.

Baswir, Revrisond,2000. Koperasi Indonesia,Yogyakarta : BPFE Yogyakarta.

Harsono, 1997. Manajemen dalam Persfektif, AMP YKPN, Yogyakarta.
I Made Agus Rusmana, I Wayan Bagia, Fridayana Yudiaatmaja,2014. Pengaruh Pertubuhan kredit bermasalah Dan Simpanan Anggota Koperasi Terhadap SHU Pada Koperasi Simpan Pinjam.E-Journal Bisma Universitas Pendidikan Ganesha Jurusan Manajemen. Volume 2 Tahun 2014.

Kuncoro, M. 2001. Metode Kuantitatif, Teori danAplikasi Untuk Bisnis dan Ekonomi.Yogyakarta: YKPN.

Laporan Pertanggungjawaban Pengurus Dan Pengawas KSU Sejati Mulia Tahun Buku 2004-2014.

Laporan Anggaran Dasar Rumah Tangga KSU Sejati Mulia.

Laporan Pertanggungjawaban Pengurus Dan Pengawas KSU Tunas Jaya Tahun Buku 2004-2014.

Laporan Anggaran Dasar Rumah Tangga KSU Tunas Jaya.

Laporan Pertanggungjawaban Pengurus Dan Pengawas KSU Ceger Jaya Tahun Buku 2004-2014.

Laporan Anggaran Dasar Rumah Tangga KSU Ceger Jaya.

Liana, 2009. Faktor-faktor yang mempengaruhiSisa Hasil Usaha pada KoperasiWaru Buana Putra, Sidoarjo, Fakultas Ekonomi, UPNJawa Timur. 


\section{Performance - Vol.23 No.2 September 2016}

Muhammad Firdaus dan Agus Edhi Susanto,2004.Perkoperasian, Ghalia Indonesia, Bogor

Narvanti, Puput dan Praningrum, 2008, PengaruhModal Usaha, Anggota, Volume Usaha pada Koperasi Manunggal Karsa, Majalah ilmiahekonomi dan pembangunan, Universitas Ratu Samban. Fakultas Ekonomi, Arga Makmur,Vol. 1, No. 1, Hal: $1-10$.

Ngongo, Petrus Bulu, 2002. FaktorFaktor Yang Mempengaruhi Partisipasi Anggota Terhadap Kinerja Koperasi. (Jurnal Elektonik) diakses pada tanggal 28 Maret 2015: www.jurnalekonomi.com

Pachta W, Andjar. 2000. Permodalan dan Perkreditan Koperasi. Yogyakarta:

Kamsius.

Pasaribu, Benny, 1996. Faktor-faktor yang Mempengaruhi Kinerja Pengusaha Kecil dan Koperasi, Bisnis Indonesia.

Partomo S.T. dan Abdul Rahman S., 2020. Ekonomi Skala Kecil/Menengah \& Koperasi. Penerbit Ghalia Indonesia, Jakarta.

Pedhazur, E. J. 1997. Multiple Regression in Behavioral Research (3rd ed.). Orlando, FL:Harcourt Brace.

Peraturan Menteri Negara Koperasi \& UKM No.: 22/Per/M.KUKM/III/
2008, Pedoman Pemeringkatan Koperasi.

Revita, 2013. Analisis Pengaruh Tingkat Simpanan Dan Pinjaman anggota Terhadap SHU Kopsyah BMT AlAmin Pekanbaru. Universitas Pasir Pengaraian Jurusan Akuntansi.

Septiasih, Retno (2009), Faktor-faktor yang Mempengaruhi Sisa Hasil Usaha pada Koperasi Pegawai Republik Indonesia di Kabupaten Rembang, Skripsi, Universitas Negeri Semarang.

Sitio, Arifin dan Halomoan Tamba, 2001.Koperasi : Teori dan Praktek, PenerbitErlangga, Jakarta.

Sukmalega, Dian, 2010. Pengaruh Permodalan dan Volume Usaha terhadap Sisa Hasil Usaha Koperasi Pegawai Negeri di Kabupaten Solok Sumatera Barat, Skripsi, Universitas Sumatera Utara.

Widiyanti, Ninik, 1991. Manajemen Koperasi,RinekaCipta,Jakarta Undang Undang Republik Indonesia No. 25 tahun 1992 tentang Perkoperasian . 